\title{
ANCIENT ROMAN OTIUM AS A CULTURAL PRACTICE AND THEORETICAL REFLECTION
}

\section{Iryna Petrova}

\section{INTRODUCTION}

Leisure is an important life-forming component of a modern society, because it reflects the characteristics of social relations, class stratification, the development of productive forces, ideology, religious beliefs and moral norms. In this context, the analysis of the driving forces and sources of the historical and cultural process is extremely important, in particular, the reconstruction of ideas about ancient Roman leisure activity as a cultural practice and a polysemantic cultural phenomenon.

The disclosing of the ancient Roman leisure practices implemented with the involvement of Strabon's geographical descriptions ${ }^{1}$, Ovidius's poetry ${ }^{2}$, Velleius Paterculus ${ }^{3}$, Titus Livius Lucius ${ }^{4}$, Claudius Cassius Dio Cocceianus's historical works ${ }^{5}$, Marcus Valerius Martialis's epigrams ${ }^{6}$, Gaius Cornelius Tacitus's annals ${ }^{7}$, Gaius Suetonius Tranquillus ${ }^{8}$ and Plutarch's biographies ${ }^{9}$, in the works which reflect the diversity of the types of cultural practices of the Roman.

About otium intelligent and otium entertaining as the opposition of individual and collective leisure activities there could be read in the Publius

\footnotetext{
${ }^{1}$ Strabon. (1964). Geografiya v 17 knigakh. (G. A. Stratanovskiy, trans.; S. L. Utchenko, ed). M.: Nauka. 941 s. (in Russian).

2 Ovidiy, P.N. (1999). Lyubovni elegiï. Mistetstvo kokhannya. Skorbotni elegiï (A. Sodomora, Trans.). Kyiv: Osnovi (in Ukrainian).

${ }^{3}$ Nemirovskiy, A. (Eds.). (1995). Malye rimskie istoriki. Velley Paterkul. Rimskaya istoriya. Anney Flor. Dve knigi Rimskikh voyn. Lutsiy Ampeliy. Pamyatnaya knizhitsa. M.: Ladomir (in Russian).

${ }^{4}$ Liviy, Tit. (1989). Istoriya Rima ot osnovaniya goroda: v III tomakh. (M. L. Gasparova \& G. S. Knabe, Ed.). M.: Nauka (in Russian).

5 Kassiy Dion Kokkeyyan. (2013). Istoriya kesarey. Knigi LVII-LXIII "Istorii rimlyan" (V. N. Talakha \& S. A. Kuprienko, Ed.). Kyiv: Vidavets Kupriєnko S. A. (in Ukrainian).

${ }^{6}$ Martsial (2000). Epigrammy. (F. Petrovskiy, Trans). Kharkov: Folio; Moscow: AST (in Russian).

${ }^{7}$ Tatsit, P. K. (2001). Annaly; Malye proizvedeniya. Istoriya [per. s lat.]. Moscow: AST; Ladomir (in Russian). (in Russian).

${ }^{8}$ Svetoniy. (1993). Zhizn dvenadtsati tsezarey. (M. Gasparov, Trans). Moscow: Nauka (in Russian).

${ }^{9}$ Plutarkh, M. (1961). Sravnitelnye zhizneopisaniya. (M. Grabar-Passek, ed.). Moscow: Akademiya nauk SSSR, pp. 382-407 (in Russian).
} 
Vergilius Maro $^{10}$, Quintus Horatius Flaccus's poems ${ }^{11}$, Gaius Plinius Caecilius Secundus's ${ }^{12}$ the Young letters, Gaius Sallustius Crispus' works ${ }^{13}$, numerous laws on luxury. Discussions as for the devaluation of spiritual leisure activity values and the reduction of leisure activity to a state of idleness are analyzed on the basis of Tacitus's works ${ }^{14}$ and Gaius Plinius Caecilius Secundus's the Young letters ${ }^{15}$.

Conceptual studies of the ancient leisure activities contain studies of foreign scientists Z. Papakonstantinou ${ }^{16}$, D. Balsdon and J.P. Vyvian ${ }^{17}$, E.K. Gazda and J.R. Clarke ${ }^{18}$, J.N. Rober ${ }^{19}$, J. Pieper ${ }^{20}$ and others. At the same time, the problem of functioning of leisure activity in ancient Rome remains without attention and scientific interest of domestic scientists, in particular, there exists contradiction between expediency on the account of ancient achievements in modern culture of leisure activity that would allow to mobilize historical and cultural experience of an era of the ancient Rome for the enrichment of leisure activity as a cultural phenomenon. This problem is of great importance partly due to the lack of scientific research in theoretical and historical trends.

That's why, the aim of our research is to analyze the ancient Roman leisure activities as a theoretical reflection and cultural practice.

\section{Ancient Roman otium as a theoretical reflection}

The spiritual transformations in the ancient Rome, changes in values-based relations ("public affairs - leisure"), public opinion and sentiments were more expressed in the life and work of Cicero. The moral consciousness of the

\footnotetext{
${ }^{10}$ Vergiliy. (1968) Georgiki. Antichna literatura: khrestomatiya. (O. Biletskiy, Ed.). Kyiv: Radyanska Shkola, pp. 433-437 (in Ukrainian).

${ }^{11}$ Goratsiy. (1982). Tvori. (A. Sodomori, Trans). Kyiv: Dnipro (in Ukrainian).

${ }^{12}$ Pliniy, Ml. (1950). Pisma Pliniya Mladshego. (A. Dovatur, Trans). Moscow-Leningrad: Nauka (in Russian).

${ }^{13}$ Sallyustiy. (1981). Sochineniya. (V. O. Gorenshteyna, trans.). Moscow: Nauka, 1981. 220 s. (in Russian).

${ }^{14}$ Tatsit, P. K. (2001). Annaly; Malye proizvedeniya. Istoriya [per. s lat.]. Moscow: AST; Ladomir (in Russian). (in Russian).

${ }^{15}$ Pliniy, Ml. (1950). Pisma Pliniya Mladshego. (A. Dovatur, Trans). Moscow-Leningrad: Nauka (in Russian).

${ }^{16}$ Papakonstantinou Z. Work and Leisure // A Cultural History of Work in Antiquity. London: Bloomsbury Academic, 2019. URL: https://www.academia.edu/37801972.

${ }^{17}$ Balsdon D., Vyvian J.P. Life and leisure in ancient Rome. Phoenix, 2002. 463 c.

${ }^{18}$ Gazda E. K., Clarke J.R. Leisure and Luxury in the Age of Nero: The Villas of Oplontis Near Pompeii. Kelsey Museum Publication, 2016. 288 p.

${ }^{19}$ Rober Zh.-N. (2004). Rozhdenie roskoshi: Drevniy Rim v pogone za moody. Moscow: Novoe literaturnoe obozrenie (in Russian).

${ }^{20}$ Pieper J. Leisure the Basis of Culture. Hardcover-Black \& White, 2010. 158 p.
} 
Romans of this time had a special structure, clearly reflecting social contradictions, intense political struggle, duality and conflict of value systems. If the grandfathers of Cicero's generation have not yet perceived themselves as autonomous individuals separated from the community and responsible for the moral content of their social behavior, then their descendants, Cicero's contemporaries, no longer doubted that moral responsibility had a personal character, because they had survived the destruction of policy system of values, spiritual experience of late stoicism, anti-Christian sentiments.

For Cicero, as a passionate supporter of the old Roman ideal of the vir bonus policy, the content of "negotium" is conditioned by the duties of a law abiding citizen with regard to res publica: after all, the homeland raised citizens to have some support from them and not to serve their convenience and create a safe shelter in leisure life and a quiet place to relax. Therefore, recreation leisure and contemplative leisure (otium) were perceived by Cicero as secondary as compared with active political activity, and as positive - only in the context of "civil peace". The thinker understood the social and political significance of leisure and its consequences in society. In particular, he condemned building of theaters, porticos and new temples, as well as entertaining battles and numerous violent scenes bringing only exhaustion and not a real pleasure, condemned luxury cost prohibitive games intended to impress the crowd. Cicero described them as it was made by Seneca one hundred years later: idle leisure can have detrimental consequences for both the individual and the entire state. Publius Servilius Rullus, tribune of the people, in his speech on the land law mentioned the ancestors who defeated the proud Campanians, providing them with "idle leisure", and this led to moral degradation and loss of independence of Capua ${ }^{21}$.

At the same time, "how happy is the Person who can say about himself what, as Cato wrote, my grandfather Publius Africanus said. And he said that he was never less alone than when alone, nor less at leisure than when at leisure"22. Cicero's leisure is inseparable from mental activities and deep reflections. Only literature that "educates us in youth, entertains us in old age, is decoration in happiness, solace in misery, comforts us at home, does no harm in foreign countries, spends the night with us, travels with us, lives with us in the countryside provides a real pleasure" 23 .

${ }^{21}$ Cicero M.T. De Lege Agraria Contra Rullum / Marcus Tullius Cicero [Electronic resourse]. URL: www.ae-lib.org.ua/texts-c/ cicero_de_lege_agraria_lt.htm.

${ }^{22}$ Ciceron, M. T. (1998). Pro derzhavu. Pro zakony. Pro pryrodu boghiv. K.: Osnovy. S. 42-43. (in Ukrainian).

${ }^{23}$ Tsitseron, M. T. (1962). Rech'v zashchitu poeta Avla Litsiniya Arkhiya. Rechi v dvukh tomakh. T. 2. Gody 62-43 do n.e. (V. O. Gorenshteyn \& M. E. Grabar'-Passek, ed.). M.: AN SRSR. S. 38. (in Russian). 
Therefore, the thinker recognizes that only otium cognitive is useful for the state, because cognitive activity has state interests. And "... a wise man should not neglect knowledge of public affairs, because he should master all that he does not know, but that he may ever need" 24 .

Cicero argued that philosophy and literature should not only fill in the leisure (otium) of the educated Roman, but also be a criterion for evaluating state activity (negotium). For Cicero, otium cum dignitate was an attempt to return to leisure its spiritual content and the "supremacy" that it lost in the Roman state, an attempt to reconcile personal pleasure and social necessity, an effort to synthesize Greek and Roman beginnings, "contemplative life" and "active life". R. Stebbins believes that Cicero, when putting forward the slogan "otium zum dignitate", meant exactly those distinctive features giving the right to identify a person with a "chosen" segment of population ${ }^{25}$.

Comparing the value and priority of public activity and leisure filled with literary and scientific activities, Cicero concluded that public duties are more in line with nature than duties resulted from cognition, and ultimately, the cognitive activity is a matter of state interest. This idea will be powerful in the future - leisure for study of sciences is useful for the state. The loss of res publica as an object of serving viri boni ("good person") was considered a condition (as a compulsory necessity) and justification for philosophical (literary) leisure. Although such a situation, according to Cicero, is an exception, but in his own life it has happened repeatedly, as confirmed by the works of Plutarch, who notes that after change of the republican system to a monarchical one, Cicero withdrew from public affairs and devoted his leisure to the sons of the most noble and influential citizens wishing to study philosophy... His main occupation was to write and translate philosophical dialogues, as well as to reproduce the terms in the sphere of dialectics and physics in Latin... His versification skills Cicero used for entertainment. Living mostly in his estate near Tuscula, Cicero wrote to his friends that he lived the life of Laertes ${ }^{26}$.

According to Cicero, the ideal state is Rome, in which there is a happy balance, relative harmony and unity of all its components, and the service to the state and civic valor is the basis of activity of the citizen. In the years of his consulate Cicero promised the Roman people the major benefits: peace, calm and leisure ("Ex quo intellegi, Quirites, potest nihil esse tam populare

${ }^{24}$ Ciceron, M. T. (1998). Pro derzhavu. Pro zakony. Pro pryrodu boghiv. K.: Osnovy. S. 34. (in Ukrainian).

${ }^{25}$ Stebbins, R. A. (2000). Svobodnoe vremya: k optimal'nomu stilyu dosuga: (Vzglyad iz Kanady) // Sotsiologicheskie issledovaniya. № 7. S. 64-72. (in Russian).

${ }^{26}$ Plutarkh, M. (1961). Sravnitelnye zhizneopisaniya. (M. Grabar-Passek, ed.). Moscow: Akademiya nauk SSSR, P. 316-377 (in Russian). 
quam id quod ego vobis in hunc annum consul popularis adfero, pacem, tranquillitatem, otium" $)^{27}$.

It is quite logical that a wise state ruler was considered by a philosopher to be a public figure able to provide the state with otium cum dignitate by preserving the traditional institutions. And, accordingly, the leisure can be positive only in the case of "civil peace" or as a result of "honorable retirement due to old age" - otium cum dignitate. This expression was set and is preserved in the language of European countries in the sense of "resignation from public affairs; leisure dedicated to science, literature and arts".

Cicero, born in the $90 \mathrm{~s}-80 \mathrm{~s} \mathrm{BC}$, attached a great importance not to public affairs, but personal ones: friendship, scientific activities, love and poetical delight. Such a transformation of views was facilitated by the spiritual crisis of Rome of the Civil War-era, loss of old ideals and intense search for new ones, uncertainty about the future, fear of gods and the future.

Sallustius, contemporary of Cicero, who at first convinced that only a person who cares about public activity, seeking good support among the public, about his valiant actions, rather than live abundantly and lounge, witnessed the rapid social transformations during the transition period (from the republic to the principate). However, not quite successful political activity of Sallustius led to the fact that he, being out of state affairs, devoted his leisure activities to history. Condemning the leisure spent on agriculture and hunting (duties of slaves), kayaking and idleness (peculiar to corrupted people), Sallustius was convinced that representation of historical events could be a kind of continuation of political activity. Therefore, he considered his literary hobbies socially significant: "The state will benefit from my leisure more than from the activities of many others" ${ }^{\prime 2}$.

In imperial Rome, the idea of stoicism became widespread: aimed at respecting the virtue, they met the Roman traditions. The doctrine of leisure of Lucius Annaeus Seneca was one of the most influential in Rome at the era of the empire. The thinker advised to live "according to nature", to contemplate what God created, to understand own needs due to own safety, modesty, courage, rejection of glory, wealth, power and high positions. The prize of life that is the "life in leisure" can be achieved by reading, reflecting on good and evil, communicating with friends, "feeding the mind" with new knowledge, "digesting" it, that is, absorbing it with soul and mind.

\footnotetext{
${ }^{27}$ Cicero M.T. De Lege Agraria Contra Rullum / Marcus Tullius Cicero [Electronic resourse]. URL: www.ae-lib.org.ua/texts-c/ cicero_de_lege_agraria_lt.htm.

${ }^{28}$ Sallyustiy. (1981). Sochineniya. (V. O. Gorenshteyna, trans.). Moscow: Nauka, 1981. S. 41. (in Russian).
} 
The main point in Seneca's works was affirmation of active or leisure (contemplative) life. His views on the problem have changed throughout his life: from prioritizing leisure in human life ("On the Shortness of Life") to active social position, which is a "true field of virtue" ("Peace of Mind") and the ability to combine practical life with contemplative life, if the "wise man" wants or needs so ("On Leisure"). However, Seneca's understanding of the nature of leisure, its impact on human (development of his physical and spiritual qualities) remained unchanged. He advised to live "according to nature", to contemplate what God created, to understand own needs due to own safety, modesty, courage, rejection of glory, wealth, power and high positions. The "life in leisure" can be achieved by reading, reflecting on good and evil, communicating with friends, "feeding the mind" with new knowledge, "digesting" it, that is, absorbing it with soul and mind ${ }^{29}$.

The destructive leisure trends are evidenced by satires of Juvenalis, who believed that it is impossible for an honest person to stay in Rome because of domination of frauds, thieves, hypocrites who spend their lives in fornication, corruption, permissiveness and cruelty of leisure forms ${ }^{30}$.

Roman thinkers understood the social and political significance of leisure, its potential power, influence (positive or negative) that it can have on human. The work of Tacitus "Life of Cnaeus Julius Agricola" refers to how Agricola, in order to teach the British peaceful existence and to curb their militancy, took the "most useful" measures, namely: encouraged to build the temples, forums, porticos, thermas; organized eloquence competitions; involved the British in banquets and entertainment. Tacitus emphasized the manipulative nature of such actions: "What was a step to further enslavement was called by them, inexperienced and simple-minded, the education and enlightenment". Knowing the burden of soldier life and considering the army as the direct support of the imperial regime, he strongly condemned leisure among military men, arguing that leisure would inevitably lead to corruption and frustration, loss of power due to pleasure and fornication, to instability of moral principles. As a result of leisure, the military men "forgot the system, duty, work strengthening the body ... idleness destroyed bodies, low passions - souls"31.

\footnotetext{
${ }^{29}$ Seneka L. A. (1996). Moral'ni lysty do Lutsiliya. (A. Sodomora, trans.). K.: Osnovy. 603 s. (in Ukrainian); Seneka, L. A. (1997). O skorotechnosti zhizni // Istoriko-filosofskiy ezhegodnik'96. S. 16-40 (in Russian).

${ }^{30}$ Juvenal. (1938). Satyra III. Nevyghody stolychni. Antychna literatura: zrazky staroghrecjkoji ta rymsjkoji khudozhnjoji literatury. (O. I. Bilecjkyj, ed.) K.: Rad. shkola. S. 441-447. (in Ukrainian). S. 442.

31 Juvenal. (1938). Satyra III. Nevyghody stolychni. Antychna literatura: zrazky staroghrecjkoji ta rymsjkoji khudozhnjoji literatury. (O. I. Bilecjkyj, ed.) K.: Rad. shkola. S. 441-447. (in Ukrainian). S. 630.
} 
Many works of Roman thinkers refer to new cultural values, justify the need to spiritually fill the leisure. Marcus Aurelius understood leisure as a means of establishing a decent, godlike life, as he concluded that nothing new could take place; everything that is, always has been; everything moves in a circle; persistence of the world is the cause of failure when it comes to reeducating people; dreaming of impossible is madness. Realizing that leisure requires a man courage, purposefulness, reliability, distinguishing himself from chance, passion, self-love, moments of fate, the emperor instructed the descendants: "Have you been distracted by something brought from the outside? Give yourself some leisure to learn something good again, stop spinning as whirligig....

\section{Ancient Roman otium as a Cultural Practice}

The question of the relationship active vita and vita competitive in the life of Roman was no argument active life with admitted priority, useful and worthy of a citizen. Therefore, the ideal leisure is, first of all, a day off from work or a day of worshiping the Gods (this is how Virgiliy described the leisure activity of the farmer) ${ }^{33}$.

The agrarian basis of the Roman community was decisive in the V-IV centuries BC and the situation has radically changed in the III-II centuries BC: as a result of victorious wars, Rome (IIIOII cent. BC) reigned throughout the Mediterranean. The expansion of Greek culture undermined the foundations of Roman morality, and the transformations in the content of "otium" changed the relationship between the duties and rights of the Romans. However, along with the awareness of the Romans of their individual values in society, there was spread the pride, hedonism, delicacy and love to luxury. Hellenistic borrowings had a double effect: on the one hand, they changed forever the structure of Roman society, on the other, they opposed to two types of social morality - work and pleasure - two opposite models of education and training ${ }^{34}$.

The acquired passion for the variety of pleasures by the Romans was constrained by numerous regulations and laws about luxury, aimed at maintaining the Roman traditions. In general, there were adopted more than

32 Avreliy M. (1993). Naedine s soboy. Razmyshleniya. (A. V. Dobrovol'skogo, Ed.). K.-Cherkassy: Real, 1993. 147 s. (in Russian).

${ }^{33}$ Vergiliy. (1968) Georgiki. Antichna literatura: khrestomatiya. (O. Biletskiy, Ed.). Kyiv: Radyanska Shkola, P. 436 (in Ukrainian).

${ }^{34}$ Rober Zh.-N. (2004). Rozhdenie roskoshi: Drevniy Rim v pogone za moody. Moscow: Novoe literaturnoe obozrenie (in Russian). 
forty laws on luxury during the III century BC and the I century AD, which were ineffective, however ${ }^{35}$.

The handover from the civil wars of the Republic to the Principate of Augustus changed the very sense of otium: from a private, individual sphere of life to a socially significant one. The destruction of Republican values led to the transformation of traditional forms of leisure activities into mass performances. It is necessary to consider the passion of the people for public entertainment, despite the religious worldview of the Roman, because religion surrounded him during the war and peacetime; its laws were subjected to the soul and body, private and public life, holidays and people's assemblies, meals and court cases. Roman life consisted of favorable (dies fasti) for work and unfavorable (dies nefasti) days for any activity. Holidays were considered unfavorable for work, because they were dedicated to the Gods. Thanks to such "feriae" (days off from work, rest days, days of obligatory leisure activity dedicated to the Gods) and "the Gods are worshipped and this is not an obstacle for everyday affairs" 36 . Holidays were a religious duty of every Roman, a duty which was as serious and important as work.

"Obligatory" leisure activities were dedicated to the Gods in Imperial Rome, there was slightly declared task - to hold power and form public opinion. This affected the number of organized "entertainments". If in the Republican period there were annually arranged national holidays, which lasted in average 109 days (Roman and Plebeian games, games of Ceres, Apollo, Cybela, Flors, the Triumph of Sulla, Saturnalia), during the Empire period the number of holidays increased to 175 . The social function of religious holidays has also changed: their own sacred significance has decreased, yielding to the value of entertainment.

Important forms of organization of leisure activity were also significant events of public life, which drew to the top of the mass of citizens. So, the opening of the Colosseum folk festival lasted during a hundred days, the end of the second Dacian war the Romans celebrated during 123 days etc. Multiday celebrations included not only the rituals of worshipping the Gods: Saturnalia, which "grew" from one day in 217 BC to seven days under the reign of Domitianus, were dedicated to worshipping the Gods only at first day, while others were given to "December freedom" (Horace). The diversity of types and the dimensions of the mass entertainment offered by the emperors to the people, reflected in the works by Lucius Claudius Cassius Dio

\footnotetext{
${ }^{35}$ Kvashnin, V. A. (2006). Zakony o roskoshi v Drevnem Rime epokhi Punicheskikh voyn. Vologda: Rus. (in Russian).

${ }^{36}$ Tatsit, P. K. (2001). Annaly; Malye proizvedeniya. Istoriya [per. s lat.]. Moscow: AST; Ladomir S. 315. (in Russian).
} 
Cocceianus $^{37}$ and Gaius Suetonius Tranquillus ${ }^{38}$, where there are mentioned usual competitions of pair and four chariots, hiking, horseback riding and sea battles; baiting of wild animals and Gladiator competitions.

Public attention to circus competitions was attracted by its splendor as well, and the opportunity to demonstrate their wealth and presence of the nobility at the competition, and entertainment and food after the circus, and the opportunity to socialize. And especially was influenced by the circus of changes in the political orientations of Roman citizens. If in the Republican period the Romans took an active part in the political life of the city, in the era of the Empire they lost the right to vote and their political function was nullified. The introduction of four factions in the circus - white, red, blue and green - was intended to create the illusion of political importance of the people. Two fractions (blue - aristocrats, green - people) had clearly defined political differences, while red and blue, creating controversy and excitement in society, supported the privileged strata of the population, the common people. Namely these "political" debates gave circus performances the greatest popularity among Roman performances ${ }^{39}$.

The aristocrats of Roman society, drowning in luxury, created a dangerous precedent, forming a social ideal of wealth and the accumulation of life's benefits, without labor, generating in the minds of free citizens a passion for wealth and idleness. In mournful elegies Ovidiy calls: "Look at your accounts for your entertainments and you be will easily convinced, Auguste, much money were spent for your entertainments" 40 . The aversion to work was so ingrained among the Roman citizens, most of whom begged without even a roof over their heads, that the ideal life was perceived as a state of inactive bliss, absolutely free from the necessity to satisfy any physical needs and actions. The people, accustomed to entertainments, fun and games, thought of spending time in fun and entertainments, the only possible and justified, "These distractions had become necessary and idleness had developed their taste"$^{, 41}$.

At the same time, the trend to control private life of the Romans, limited in the period of the Republic of Patriarchal dogmas and the suppression of

${ }^{37}$ Kassiy Dion Kokkeyyan. (2013). Istoriya kesarey. Knigi LVII-LXIII "Istorii rimlyan" (V. N. Talakha \& S. A. Kuprienko, Ed.). Kyiv: Vidavets Kupriєnko S. A. (in Ukrainian).

${ }^{38}$ Svetoniy. (1993). Zhizn dvenadtsati tsezarey. (M. Gasparov, trans). Moscow: Nauka, P.74-100; P. 202-207; P. 208-219.

39 Martsial (2000). Epigrammy. (F. Petrovskiy, Trans). Kharkov: Folio; Moscow: AST (in Russian). S. 277.

40 Ovidiy, P.N. (1999). Lyubovni elegiï. Mistetstvo kokhannya. Skorbotni elegiï (A. Sodomora, Trans.). Kyiv: Osnovi (in Ukrainian). S.204.

41 Martsial (2000). Epigrammy. (F. Petrovskiy, Trans). Kharkov: Folio; Moscow: AST (in Russian). S. 111. 
luxury, turned into the Imperial epoch on the monitoring forms of entertainment. Special attention of the authorities was attracted by the associations of leisure activities type: colleges, groups and taverns ${ }^{42}$. The government controlled religious activities of its citizens as well, in particular inhibiting (enabling) to implement new Gods into Panthenon. In end, this led to a complete mismatch of folk rituals that existed within the masses and the official religion. The culmination stage of the formation of leisure activity on the level of state policy of the Roman rulers was the deification of the emperors and the spread of religious rituals on them.

The state ideas of the Empire were most fully embodied in the construction of buildings for purely practical purposes, including in the sphere of leisure activity. Hence, the active construction of forums, baths, porticos, gardens, among which the life of the Roman passed, full of a huge number of ceremonies, participation in which was obligatory. Gymnasiums, palaestras, porticos, baths, poultry houses, menageries, this was all "surplus" with the help of which Roman citizens tried to assert their social position in society. The passion for excessive luxury in the days of the Empire has become almost the only sign of the person's belonging to the privileged class. Not surprising is the fact that for a short time, public establishments, and private homes the privileged elite of Roman society evolved into real museums. A new type of Roman was formed a private collector. The expansion of Hellenistic culture, as a result of which ancient Rome was flooded not only with works of art, but also with foreign artists, philosophers, poets, whose activities contributed to the passion of the Romans for artistic works, was a powerful impetus to the development of leisure activity, saturated with aesthetic and intellectual pleasures.

Was it the basis for the development of the real artistic taste of the Romans, which they didn't have before the conquest of Syracuse in 212 BC according to Plutarch's words nothing beautiful, attractive and sophisticated $?^{43}$. The answer to the question is in the formation of a new socio-psychological type of personality - the Roman intellectual. The intellectuals of Rome were United into circulus (lit. - circle), prototypes of modern interest clubs to discuss philosophical, literary problems, issues of political and national importance. The formation of the Roman intelligentsia (Mark Terentius Varron, Publius Cornelius Lentulus, Mark Celius Ruf, Mark Gullius Cicero, Cornelius Nepot, Gaius Valerius Catullus, Lucretius Carus

\footnotetext{
${ }^{42}$ Tatsit, P. K. (2001). Annaly; Malye proizvedeniya. Istoriya [per. s lat.]. Moscow: AST; Ladomir. S. 132-133. (in Russian).

${ }^{43}$ Plutarkh, M. (1961). Sravnitelnye zhizneopisaniya. (M. Grabar-Passek, ed.). Moscow: Akademiya nauk SSSR, pp. 382-407 (in Russian). S. 396.
} 
and others) was also influenced by Greek culture: Greek logic transformed Roman thought, and the assimilation of techniques and methods of intellectual activity of the Hellenistic world enriched the Roman elite. However, intellectual maturity, reached the Roman Republic in the last days, contributed not only to the Greek borrowing, but also the interpenetration and synthesis of Roman and Greek cultures.

Modification of the ideal vir bonus demanded a valorous Roman, in addition to purely traditional qualities that are important for an active participant in the life of the civitas - virtus, fortitudo, constantia, fides, pietas, dignitas, gravitas, auctoritas - and also education, specific knowledge, ability to self-improvement, which is partly embodied in new qualities - urbanitas and humanitas. The intellectual elite of the ancient Rome tried to distance themselves from the motley of aristocratic elite of the society with the originality of the life and culture of everyday life that carried out their leisure time in entertainment and idleness.

Thus, Virgiliy created his "Bukoliki" in the conditions of rural solitude, which provided the poet with wise serenity, spiritual and mental peace. The real intellectual, spiritual sweetness, according to Virgiliy, is the result of poetic meditation, intense mental search for the truth of life. The train to calm happiness, peace and freedom of the soul is reflected in Horace's work, who tried to realize his life concept at the Villa presented by the Patron in Sabine. Horace repeatedly complained that the people expected from the performances only entertainment: from comedies to fights, from tragedies to luxurious triumphal processions.

If the city was considered the accumulation of unnecessary worries, the rural life was a refuge from them and the possibility of free otii. After all, the intellectual otium required a special atmosphere corresponding to the lifestyle and the surrounding space. An important emphasis in this discourse was on a decent old age, accompanied by "leisure activity with dignity", pointing not only onto the civilization of society, but also to the high level of aestheticism of everyday life (remember the letters of Pliniy the Young). The philosophy of intellectual feast was opposed by Lukull's feasts of luxurious idlers who were not capable of "high" intellectual games.

The growth of interest in the philosophy of scientific and literary work was reflected in the middle of the I century and has gained popularity in this form of activities including public readings, which contributed the involvement of intellectual activities to a wide readership.

\section{CONCLUSIONS}

The ideology and the system of values of the Roman was determined by patriotism, and the ideal model of the citizen was courageous, persistent, loyal 
to the state, temperate in the pleasures of a disciplined citizen. The main focus on economic equality formed social psychology, focused on moderation in consumption and everyday life as a norm. It is the working morality of the people frugal and modest, valuing labor, condemning luxury and extravagance. Consequently, the leisure was perceived as a rest from labor, a day dedicated to the worshipping of the God, enjoyment, safe for moral values (Virgiliy, Georgiki).

Due to the conquests in the East and the expansion of Greek culture, the system of values of the Romans underwent significant changes. A new type of person was formed, whose social functions were reduced not only to political activity, performance of military duties and observation of religious rites but, first of, various pleasures. The consequence of the loss of stable moral principles, adapted to the aggressive policy, was the cult of pleasure and prestige, which was clearly manifested in the transformation of the content of leisure activity.

The coexistence of particularism and universalism was typical for many spheres of spiritual life, the contradictions between official ideology and reality, the discord between the individual and the state, rights and duties, collectivism and individualism, the spirit of self-sacrifice and the thirst for pleasure led to the functioning and development of leisure activity in two interrelated "spheres": entertainment and intellectual. The performance is not just a mass action, it is the main collective pleasure to which the subjects had the right, it is the only luxury available to the poor. Hence, reducing the content of leisure to "bread and entertainment", "money and pleasure", the gradual loss of the majority of the ability to perceive leisure activity as a means of self-development, self-improvement and cultural creativity.

For the representatives of the Roman intelligentsia it was typical to have high level of education, mastering the complex intellectual work, and most importantly - self-realization in the intellectual sphere of activity intellectual otium. However, for the majority of the population, the Roman borrowing of otium graecum did not have an introspective, self-absorbed social character, freed from a sense of moral responsibility, it required only an external, leveled assessment, contrary to the individual-spiritual content of culture.

\section{SUMMARY}

The aim of the research is to analyze the ancient Roman leisure activity as a theoretical reflection and cultural practice. The methodology of the research is reduced to the usage of historical and cultural approach that allows to combine diachronic and synchronic methods to the study leisure activity as a polysemantic cultural phenomenon. The topicality of the 
research is to identify and substantiate the conditions that led to the formation and development in ancient Rome intellectual and entertainment leisure activities, contemplative and active leisure activities, leisure activity as a means of self-development and leisure activity as a mass cultural practice. Conclusions. Leisure activity was perceived as a rest from work, a day dedicated to the God, pleasure, safe for moral values (Virgiliy, Georgiki) in Republican Rome. As a result of the conquests in the East and the expansion of Greek culture, the value system of the Romans underwent significant changes, which was clearly manifested in the development of leisure activity in two interrelated "spheres": spectacular and intellectual. Spectacular otium has become a powerful tool of political impact on masses, a method of mobilization and employment, and consequently reducing the content of leisure activity to "bread and sights", "money and pleasure", the gradual loss of the majority the ability to perceive leisure as a means of selfdevelopment, self-improvement and cultural creation. For members of the Roman intelligentsia leisure activity is, first of all, the luxury of companionship, intelligent conversation and literature classes. However, for the majority of the population, the Roman borrowing of otium graecum didn't have an introspective, self-absorbed social character, freed from a sense of moral responsibility, it required only an external, leveled assessment, contrary to the individual and spiritual content of culture.

\section{REFERENCES}

1. Avreliy M. (1993). Naedine s soboy. Razmyshleniya. (A. V. Dobrovol'skogo, Ed.). K.-Cherkassy: Real, 1993. 147 s. (in Russian).

2. Vergiliy. (1968) Georgiki. Antichna literatura: khrestomatiya. (O. Biletskiy, Ed.). Kyiv: Radyanska Shkola, pp. 433-437 (in Ukrainian).

3. Vergiliy. (1968) Yeneïda. Antichna literatura: khrestomatiya (O. Biletskiy, Ed.). Kyiv: Radyanska Shkola, pp. 437-458 (in Ukrainian).

4. Goratsiy. (1982). Tvori. (A. Sodomori, Trans). Kyiv: Dnipro (in Ukrainian).

5. Kassiy Dion Kokkeyyan. (2013). Istoriya kesarey. Knigi LVII-LXIII "Istorii rimlyan" (V. N. Talakha \& S. A. Kuprienko, Ed.). Kyiv: Vidavets Kupriєnko S. A. (in Ukrainian).

6. Kvashnin, V. A. (2006). Zakony o roskoshi v Drevnem Rime epokhi Punicheskikh voyn. Vologda: Rus. (in Russian).

7. Liviy, Tit. (1989). Istoriya Rima ot osnovaniya goroda: v III tomakh. (M. L. Gasparova \& G. S. Knabe, Ed.). M.: Nauka (in Russian).

8. Nemirovskiy, A. (Eds.). (1995). Malye rimskie istoriki. Velley Paterkul. Rimskaya istoriya. Anney Flor. Dve knigi Rimskikh voyn. Lutsiy Ampeliy. Pamyatnaya knizhitsa. M.: Ladomir (in Russian). 
9. Martsial (2000). Epigrammy. (F. Petrovskiy, Trans). Kharkov: Folio; Moscow: AST (in Russian).

10. Ovidiy, P.N. (1999). Lyubovni elegiï. Mistetstvo kokhannya. Skorbotni elegiï (A. Sodomora, Trans.). Kyiv: Osnovi (in Ukrainian).

11. Pliniy, Ml. (1950). Pisma Pliniya Mladshego. (A. Dovatur, Trans). Moscow-Leningrad: Nauka (in Russian).

12. Plutarkh, M. (1961). Sravnitelnye zhizneopisaniya. (M. Grabar-Passek, ed.). Moscow: Akademiya nauk SSSR, pp. 382-407 (in Russian).

13. Rober Zh.-N. (2004). Rozhdenie roskoshi: Drevniy Rim v pogone za moody. Moscow: Novoe literaturnoe obozrenie (in Russian).

14. Sallyustiy. (1981). Sochineniya. (V. O. Gorenshteyna, trans.). Moscow: Nauka, 1981.220 s. (in Russian).

15. Svetoniy. (1993). Bozhestvennyy Tit. Zhizn dvenadtsati tsezarey. (M. Gasparov, trans). Moscow: Nauka, pp. 202-207 (in Russian).

16. Svetoniy. (1993). Domitsian. Zhizn dvenadtsati tsezarey. (M. Gasparov, Trans). Moscow: Nauka, pp. 208-219 (in Russian).

17. Svetoniy. (1993). Tiberiy. Zhizn dvenadtsati tsezarey. (M. Gasparov, Trans). Moscow: Nauka, pp. 74-100 (in Russian).

18. Seneka L. A. (1996). Moral'ni lysty do Lutsiliya. (A. Sodomora, trans.). K.: Osnovy. 603 s. (in Ukrainian).

19. Seneka, L. A. (1997). O skorotechnosti zhizni // Istoriko-filosofskiy ezhegodnik'96. S. 16-40 (in Russian).

20. Stebbins, R. A. (2000). Svobodnoe vremya: k optimal'nomu stilyu dosuga: (Vzglyad iz Kanady) // Sotsiologicheskie issledovaniya. № 7. S. 64-72. (in Russian).

21. Strabon. (1964). Geografiya v 17 knigakh. (G. A. Stratanovskiy, trans.; S. L. Utchenko, ed). M.: Nauka. 941 s. (in Russian).

22. Tatsit, P. K. (2001). Annaly; Malye proizvedeniya. Istoriya [per. s lat.]. Moscow: AST; Ladomir (in Russian). (in Russian).

23. Tsitseron, M. T. (1993). O starosti, o druzhbe, ob obyazannostyakh. (V. O. Gorenshteyn, ed.). M.: Nauka. 245 s. (in Russian).

24. Tsitseron, M. T. (1962). Rech' v zashchitu poeta Avla Litsiniya Arkhiya. Rechi $\mathrm{v}$ dvukh tomakh. T. 2. Gody $62-43$ do n.e. (V. O. Gorenshteyn \& M. E. Grabar'-Passek, ed.). M.: AN SRSR. S. 33-42. (in Russian).

25. Tsitseron, M. T. (1962). Rech' protiv Gaya Verresa: [Vtoraya sessiya, kniga IV, "O predmetakh iskusstva". 70 g.]. Rechi v dvukh tomakh. T. 1. Gody 81-63 do n.e. (V. O. Gorenshteyn \& M. E. Grabar'-Passek, ed.). M. : AN SRSR. S. 59-109. (in Russian).

26. Ciceron, M. T. (1998). Pro derzhavu. Pro zakony. Pro pryrodu boghiv. K.: Osnovy. 476 s. (in Ukrainian). 
27. Epiktet. (1995). V chem nashe blago? Aforizmy. Rimskie stoiki: Seneka, Epiktet, Mark Avreliy. (V. V. Sapova, ed.). M.: Respublika. S. 206-270. (in Russian).

28. Juvenal. (1938). Satyra III. Nevyghody stolychni. Antychna literatura: zrazky staroghrecjkoji ta rymsjkoji khudozhnjoji literatury. (O. I. Bilecjkyj, ed.) K.: Rad. shkola. S. 441-447. (in Ukrainian).

29. Balsdon, D., \& Vyvian, J.P. (2002). Life and leisure in ancient Rome. Phoenix (in English).

30. Cicero M.T. De Lege Agraria Contra Rullum. URL: www.ae-lib.org.ua/texts-c/ cicero_de_lege_agraria_lt.htm. (in English).

31. Gazda, E. K., \& Clarke, J.R. (2016). Leisure and Luxury in the Age of Nero: The Villas of Oplontis Near Pompeii. Kelsey Museum Publication (in English).

32. Papakonstantinou, Z. (2019). Work and Leisure. A Cultural History of Work in Antiquity. London: Bloomsbury Academic. Retrieved from: http://www.academia.edu/37801972/_Work_and_Leisure_in_E._Lytle_ed._A _Cultural_History_of_Work_in_Antiquity_London_Bloomsbury_Academic_ 2019 (in English).

33. Pieper, J. (2010). Leisure the Basis of Culture. Hardcover-Black \& White (in English).

Information about the author: Petrova Iryna,

Doctor of Sciences in Cultural Studies, professor of Event-Management and Leisure Industry Department, Kyiv National University of Culture and Arts office 415, 36, Konovalets str., Kiev

ORCID 0000-0002-8146-9200 